\title{
Student Actions in the Learning Process of Indonesian Language Subjects and Their Implications for Improving Discussion Ability
}

\author{
Perida Roma Asi Siahaan ${ }^{1}$, Erikson Saragih ${ }^{2}$ \\ ${ }^{1,2}$ Universitas Prima Indonesia, Indonesia \\ perida_sml@yahoo.com,erikson.saragih@unprimdn.ac.id
}

\section{Abstract}

This study aims to analyze the types, functions and implications of students' speech acts, how the speech acts in speaking directly to students in class discussion activities in the Indonesian language subject at the Faculty of Economics, University of Prima Indonesia. This research method uses mequalitative descriptive research tode with a case study research design for Faculty students Economics of Prima Indonesia University, where the research data were collected using technique note, the method of observation, and listen. Sources of data were obtained from the results of students' speech acts in the learning process of discussing Indonesian Language courses. Types of speech acts used in discussion activities in the learning process are locus speech acts, illocutionary speech acts and perlocution speech acts. The speech act function used by students in discussion activities in the learning process is a locus speech act with a news function, with a question-speaking function, with a commanding speech function. Assertive illocutionary speech acts, directive illocutionary speech acts, expressive illocutionary speech acts, commissive illocutionary speech acts, and declarative illocutionary speech acts. Perlocutionary speech acts with the function of giving influence.
Keywords

pragmatics, speech actions, discussion; learning process

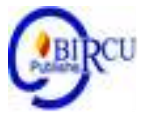

\section{Introduction}

Language is basically a tool for interaction or a means of communicating, to convey thoughts, ideas, concepts, or feelings (Chaer and Agustina, 2004: 14). Language in general is a system of speech sound symbols used to communicate by the user community. A good language develops based on a system, namely a set of rules that are obeyed by the user. Language itself functions as a means of communication as well as a means of integration and adaptation. Language is an arrangement of arbitrary symbols possessing an agreed-upon significance within a community. These symbols can be used and understood independent of immediate contexts, and are connected in regular ways. Naturally individual has the typical language characteristics which are influenced by the feeling, idea, emotion, situation and condition, articulation and cognition. (Ramlan, 2018)

Language is an arrangement of arbitrary symbols possessing an agreed upon significance within a community; furthermore, these symbols can be used and understood independent of immediate contexts, and they are connected in regular ways. In line with this definition, therefore, it acceptable to state that language has the great roles in human's lives because it is used as a means of communication among the member of the society. Whatever 
in a certain ethnics something being conveyed to another person can not be done without the language. (Ramlan, 2018)

Some of the events that occurred in the community, there were clashes or incidents due to communication errors, misunderstanding, or offense as reported by many today through print media, social media, television media, and the like. One form of incident that often occurs in academia or in the world of education and teaching. In fact, it is the academic community that should become an example or role model for other communities because in this world, the education of language or spoken characters is a place. This is especially needed in the process of learning interaction, especially among students where the campus environment is very good at forming a good speech from each student, because the speech is good, memorable,

Speech art (speech art) is a pragmatic element that involves the speaker, listener or reader as well as what is being discussed. In its application, speech acts are used by several disciplines. According to Chaer (2004: 16) speech acts are an individual symptom, psychological in nature and their sustainability is determined by the speaker's language ability in dealing with certain situations. The speech act theory is further elaborated by linguists including JL Austin (in AH Hasan Lubis, 1991: 9) states that pragmatically, there are at least three types of actions that a speaker can manifest in performing speech acts, namely local speech acts, speech acts. Illocutionary, and perlocutionary speech acts (Hartyanto, 2008).

In this case, the speech acts of students in tertiary institutions are very important to pay attention to, because these students will later engage in society to serve the community. Based on the above background, the formulation of the problems in this study can be drawn, namely: (1) what types of speech acts are used by students in the Indonesian Language Learning Process at the Faculty of Economics, Prima Indonesia University? (2) What are the functions of the speech acts used by students in discussion activities in learning Indonesian Language at the Faculty of Economics, Universitas Prima Indonesia? (3) What are the implications of the use of language speech acts by students in discussion activities on Indonesian language learning at the Faculty of Economics, Universitas Prima Indonesia?

\section{Reseach Methods}

The design used in this research is descriptive qualitative. Descriptive research is research that seeks to address existing problem solutions based on data. This type of qualitative descriptive research used in this study is intended to obtain in-depth and comprehensive information about the speech acts of students in the discussion learning process at the Faculty of Economics, Prima Indonesia University. In addition, with a qualitative approach it is hoped that the situation and problems faced in speech act activities can be expressed in discussions in the Indonesian language learning process.

This researcher is focused on the speech acts of students in the Indonesian language learning process at the Faculty of Economics, Universitas Prima Indonesia. Qualitative descriptive research is research that identifies, classifies, analyzes the data that has been obtained, and the descriptions are in the form of describing language as it is (Sudaryanto, 1993: 62). This research is a study that describes the speech acts of students in the discussion learning process in the Indonesian language course in accounting study program students, Faculty of Economics, Universitas Prima Indonesia, Medan. This research was conducted at the Faculty of Economics, Universitas Prima Indonesia. The research subjects were students at the Faculty of Economics, UNPRI during the learning discussion process which examined 
the speech acts used by students in the discussion process at the Faculty of Economics, UNPRI.

The subjects of this study were students in the Indonesian language course, the Accounting Study Program of the Faculty of Economics, Universitas Prima Indonesia in the 2019 academic year stage 1, the researcher chose the fifth semester students of the Accounting study program because the Indonesian language course was studied in the fifth semester in odd semesters, and the Indonesian Language course curriculum. Obtained in odd semesters by students of the Faculty of Economics, Universitas Prima Indonesia, researchers want to see natural learning situations carried out by lecturers and students where natural and actual situations will only be known by seeing directly when the teaching and learning process takes place in the classroom, especially in the process of catch-up. discuss and because it is considered as a source that can provide information selected according to its purpose.

Data analysis techniqueThis is done by transcribing data into written form, identifying forms of speech acts that have been transferred to written form, and presented in the form of descriptions as they are. Sources of data were obtained from the results of students' speech acts during the discussion learning process at the Faculty of Economics, Universitas Prima Indonesia. Data collection in this study was carried out using observation techniques, listening techniques and note-taking techniques so that researchers only observe, listen and take notes. Observation is used to see the speech acts of students in the learning process during discussion, observation is a complex process, a process composed of various biological and psychological processes, and the two most important data are the processes of observation and memory in terms of implementing data collection.

The listening method is a method used to obtain data by listening to the use of language through the speech act process of students in the learning process of discussing in class. Notetaking technique is used to record every speech act used in the discussion learning process. The note-taking or writing technique is a technique for recording the utterances delivered by students during the discussion learning process to strengthen the data obtained through the listening technique. When conducting research, the researcher is not involved in conversational events, or only acts as an observer, or what is commonly called the free-tospeak listening technique. Researchers observed all forms of student speech acts in the discussion learning process. This observation method is used to find out directly the form and form of how the students' speech acts are in the discussion learning process during the learning process that takes place in the classroom.

The form of class interaction is manifested in the form of conversation during the discussion process between students and students in the classroom. Where the discussion process begins when the moderator greets the lecturers and students opens the presentation by introducing each of the group members, presenting or explaining the material and opening a question and answer session to students from other groups. It can be said that class discourse is a conversational discourse that has an exchange structure that characterizes an interaction. In an exchange in a conversation, it consists of several components forming an exchange. These components are initiation, response and feedback.

The lecture material presentation was conducted in groupsThe presentation usually takes 15-20 minutes and for a question and answer session about 15 minutes. The presentation of lecture materials usually ends with a question and answer session and discussion. In the discussion process during the presentation, each group advances to present their group material. Presentations are delivered by reading papers, reading slides with powerpoints that have been prepared by the presenter, by first giving the opening greetings to the lecturers of the course and the audience where the audience is students before starting the 
presentation, usually the moderator of each group will introduce themselves from each group team who will advance the percentage either as a moderator or as a presenter.

After the material presentation process is complete, continue with a question and answer session by students from other groups, the moderator invites students to ask questions in accordance with the material presented by the presenter, usually for the question and answer session is opened in three stages, where the questions asked by students from different groups From the interactions that occur between lecturers and students, the term teaching-learning process emerges. According to Usman (2005: 4), the teaching-learning process is a process that contains a series of actions by teachers and students on the basis of a reciprocal relationship that takes place in an educational situation to achieve certain goals.

\section{Discussion}

Based on the results of data analysis, it was found that the description of the types of speech acts used by students in students' speech acts in the learning process of the Indonesian language course and its implications for improving the ability to discuss students in the accounting study program at the Faculty of Economics, Prima Indonesia University in the 2019 academic year stage 1 are as follows:

1. Locutionary act

2. Illocutionary act, and

3. Perlocutionary act.

Judging from the learning process in the classroom at the time of opening the presentation and when presenting the material related to the material that has been distributed, then when opening the question and answer session, the type of location speech acts are in the form of news (statements), questions and orders. The location of news forms dominates in the process of discussion learning activities held in the classroom, then the form of questions and orders. Judging from the illocutionary speech acts, we find assertive, directive, expressive, commissive and declarative illocutionary acts. Where the forms of assertive illocutionary speech appear the most in this study, followed by directive, expressive, declarative and finally commissive.

Types of Speech Actions used by students in the process of learning Indonesian Language courses during the discussion learning process. The following will be described

\subsection{Locutionary Act}

Locus speech acts are speech acts that are meant to express something; act of saying something with the word and the meaning of the sentence according to the meaning of the word.

\section{a. Speech Action Locates the Meaning of Telling the Form of a Statement (Declarative) Examples of speeches using this type of speech are:}

Context: The moderator in the classroom when opening the group presentation with the opening greeting by greeting the lecturers and other students and introducing themselves before starting the presentation.

Moderator: " Good morning, the lecturer who teaches the course and friends, we from group I will discuss the results of our group discussion entitled Variety of Languages, for the material to be delivered by my friend the presenter, the time and place we will invite ". 
b. The Action of the Locus Expresses the Meaning of Asking / the Form of the Question (Interrogative)

The following is an example of his speech.

Context: When the presenter finishes making a presentation and opens a question and answer session by asking other students if anyone wants to ask questions from the results of the material that has been explained.

Presenter: " Thus the presentation of the paper from our group, we will open a question and answer session, we invite three questioners from each group to ask questions, we invite each group, if anyone wants to ask a question, we invite".

\section{c. Action of Locus Speech Expresses the Meaning of Ordering / Forms of Orders (Imperative) \\ Examples of speeches using this type of speech are:}

Context: On when the question and answer session was in progress, the moderator asked the students who asked questions to be able to repeat their questions again.

Moderator: "Thank you Ratna for the question, but may the question be repeated so that it is clearer"!

\subsection{Illocutionary Act}

Direct speech acts in classroom learning are found in all assertive, directive, commissive, expressive, and declarative illocutionary acts. This direct illocutionary act is conveyed in two ways, namely directly to the target and directly with arguments / reasons.

\section{a. Assertive Illocutionary Actions}

The assertive speech used by students in the learning process of Indonesian Language courses in the discussion learning process contains a lot of speech which is information conveyed by speakers who are students to speech partners, namely other students. The following is an example of an assertive speech act in the discussion learning process.

Examples of speeches using this type of speech are:

Context: Students in the classroom when making suggestions or making suggestions.

College Student: "I from group 5 would like to suggest that maybe every time you want a presentation to the class you have to study the contents of the paper first so you don't get stuck with the text."

\section{b. Directive Illocutionary Actions}

A directive is a speech act that is meant by the speaker so that the speech partner performs the actions mentioned in the speech. A directive is what the speaker does with the intention of making the interlocutor do something, namely ordering, begging, demanding, suggesting, ordering, asking and challenging.

Examples of speeches using other types of directive illocutionary speech are:

Context: Audience (student) in the classroom when asking the presenter to display the slides in CHAPTER III.

College student: "Sorry to Brother Toni in advance, please re-display the slides in CHAPTER

III. Earlier you explained about persuasive text, how about for example"?

\section{c. Commissive Illocutionary Actions}

Commissive speech acts are speech acts that bind the speaker to carry out everything that is stated in his utterance, for example swearing, promising, threatening, declaring commitment. 
Examples of speeches using this type of speech are:

Context: The moderator in the class closed the presentation and promised to improve their paper.

Moderator: "That is the result of the percentage of our group, we know that there are still many mistakes and shortcomings in the content of our group's paper, and we promise to correct the mistakes in the content of our paper and will submit the corrections to our lecturers who teach our courses, for the suggestions and questions from our audience friends, we thank you".

\section{d. Expressive Illocutionary Actions}

Expressive Illocutionary speech acts are speech acts intended by the speaker so that the speech is interpreted as an evaluation of the things mentioned in the speech, including utterances of thanking, complaining, congratulating, flattering, praising, blaming, and criticizing.

Examples of speeches using this type of speech are:

Context: Students at the time invite the presenter to add an explanation of the material presented because other students do not understand the material being explained.

Moderator: "Previously, I would like to say thank you, we ask the presenter to add more explanations because we don't understand the slides in the third slide, please add or explain again".

Examples of speeches using expressive speech types in saying thank you are:

Context: The moderator in the class at the time said thank you for the opportunity to be given the presentation.

Moderator: "Thank you for the opportunity given, we from group one will present the results of our discussion. Our friends are welcome."

\section{e. Declarative Illocutionary Actions}

This declarative illocutionary act is an illocution which, if its performance is successful, will cause a good correspondence between propositional and reality. As for some of the functions of declarative speech contained in the speech of a speaker to speech partners, it can function to surrender, fire, release, baptize, name, excommunicate, point, impose punishment, sentence and so on.

Context: The moderator in the class opens the question and answer session during the presentation.

Moderator: "I will open the second session for question and answer, to friends who want to ask more questions we welcome."

\subsection{Perlocutionary Act}

Perlocutionary speech acts are actions to influence interlocutors such as embarrassing, intimidating, cajoling, and others (Nadar, 2009: 15).

Examples of speeches using this type of speech are:

Context: The presenter in the class when convincing his friends as the audience to be able to understand the results of the presentation or the material presented by the presenter team.

Presenter: "Now as we have explained earlier those language skills that must be possessed by students and can develop the ability to listen, speak, read, and especially write and therefore, students as young intellectuals, as the front guard in defending the nation and state, have should have mastered the four language skills."

The results of this study describe the results of student speech actions in the learning process of Indonesian language courses and their implications for improving discussion 
skills. In this case, it relates to the speech acts of students with the types of speech acts, the function of speech acts and their implications in improving the learning process in discussion. Where the types of speech acts found in discussion activities in Indonesian Language learning at the Faculty of Economics, Universitas Prima Indonesia include speech acts of locus, illocution and perlocution.

\section{Conclusion}

Based on the research findings, the authors conclude that there are three types of speech acts used in discussion activities in the learning process in the Indonesian Language course, namely local speech acts, illocutionary speech acts and perlocution speech acts. The speech act functions used by students in discussion activities in the learning process in the Indonesian Language Course are as follows: locus speech acts with a news function, locus speech acts with a question speech function, locus speech acts with a commanding speech function. Assertive illocutionary speech acts, directive illocutionary speech acts, expressive illocutionary speech acts, commissive illocutionary speech acts, and declarative illocutionary speech acts. Perlocutionary speech acts with the function of giving influence are used in the speech act function in the discussion learning process.

\section{References}

A.A. Anwar Prabu Mangkunegara (2010). Evaluasi Kinerja SDM, PT.Refika Aditama, Bandung.Bangun, Wilson, 2012, Manajemen Sumber Daya Manusia, Erlangga, Bandung

AM, S. (2006). Teaching and Learning Interaction and Motivation. Jakarta: Raja Grafindo Persada.

Amin, N. (2018). Analysis of Lecturer Actions in Learning Interaction and. Tamaddun, Arikunto, S. (1990). Basics of Educational Evaluation. Jakarta: Earth Literacy.

Ambar Teguh Sulistiyani. (2003). Manajemen dan Sumber Daya Manusia : Konsep Teori dan Pengembangan Dalam Konteks Organisasi Publik. Yogyakarta: Graha Ilmu. Hal. 223.

Amelia, A. (2015). Implementasi Supervisi Akademik Oleh Pengawas SMA Pada Guru Mata Pelajaran Bahasa Indonesia Di Kota Medan. Program Pascasarjana. Universitas Negeri Medan.

Arif, Syamsul. (2019). Influence of Leadership, Organizational Culture, Work Motivation, and Job Satisfaction of Performance Principles of Senior High School in Medan City. Budapest International Research and Critics Institute (BIRCI-Journal), 239-254.

Austin, J. (1975). How To Do Things with Words. Harvard: Harvard University Press.

As'ad, Moh. (2005). Psikologi Industri. Edisi Keempat. Yogjakarta. Liberty

Barnawi dan Mohammad Arifin. (2014). Kinerja Guru Profesional: Instrumen Pembinaan, Peningkatan dan Penilaian. Jogjakarta: Ar-Ruzz Media.

Chaer, A. d. (1995). Sociolinguistics. Jakarta: Rineka Cipta.

Chaer, A. d. (2004). Early Introductory Sociolinguistics. Jakarta: Rineka Cipta.

Chaer, A. d. (2004). Early Introductory Sociolinguistics. Jakarta: PT Rineka Cipta.

Coulthard, M. (1985). Introduction to Discourse Analysis. London: Longman.

Dahar, RW (1996). Learning Theories. Jakarta: Erlangga.

Dr.H.Nur Fajar Arief, M. (2015). Teacher's Speech Actions in Class Discourse. Poor.

E. Mulyasa. (2005). Menjadi Guru Profesional Menciptakan Pembelajaran Kreatif dan Menyenangkan, Bandung: Remaja Rosda Karya 
Hasibuan, Malayu, SP. (2017). Manajemen Sumber Daya Manusia Edisi Revisi. Jakarta: Bumi Aksara

Hasibuan, MS (1985). Basic Understanding And Problems. Jakarta: Earth Literacy.

Ibn, d. (2003). Research Methodology Basics. Padang: UNP.

Iqbal., HM (2002). Statistics Material 1 (Descriptive Statistics). Jakarta: PT. Earth Literacy.

Kridalaksana, H. (2008). Linguistic Dictionary. Jakarta: Gramedia Pustaka Utama.

Leech, G. (1993). Pragmatic Principles. Jakarta: University of Indonesia.

Levinson, SC (1983). Pragmatics. Cambridge: Cambridge University Press.

Nababan, PW (1987). Pragmatics (Theory and Its Application). Jakarta: Ministry of Education and Culture.

Mahsun. (2007). Language Research Methods. Jakarta: PT Raja Grafindo Persada.

Nasution. (1998). Qualitative Research Methodology. Bandung: Tarsito.

Nawawi, Hadari. (2006). Evaluasi Dan Manajemen Kinerja Di Lingkungan Perusahaan Dan Industri. Yogyakarta: Gadjah Mada University Press

Purba, K and Sudibjo, K. The Effects Analysis of Transformational Leadership, Work Motivation and Compensation on Employee Performance in PT.Sago Nauli. Budapest International Research and Critics Institute-Journal (BIRCI-Journal). P. 1606-1617.

Ramlan. (2018). Some Steps for Language Maintenance in the Society and Individual. Budapest International Research and Critics Institute-Journal (BIRCI-Journal). P. 62-71

Ramlan. (2018). Language Standardization In General Point of View. Budapest International Research and Critics Institute-Journal (BIRCI-Journal). P. 27-33

Riva'i, M. (2015). Administrasi dan Supervisi Pendidikan - Jilid 1. Bandung: Yenmars

Richard West dan Lynn H. Turner. (2008). Pengantar Teori Komunikasi: Analisis Dan Aplikasi. Terjemahan Maria Natalia Damayanti Maer. Jakarta: Salemba Humanika. Hal. 317.

Robert L. Mathis dan John H. Jackson. (2006). Human Resource Management: Manajemen Sumber Daya Manusia. Terjemahan Dian Angelia. Jakarta: Salemba Empat.

Robbins, P.S. (2006). Organizational Behavior, (9th Edition), New York : Prentice Hall International.

Robert Kreitner dan Angelo Kinicki. (2005). Perilaku Organisasi (Orgaizational Behavior). Jakarta: Salemba

Samani, MH (2012). Character building. Bandung: PT Remaja Rosdakarya.

Schiffrin, D. (2007). Discourse Study Ideas. Yogyakarta: Learning Library.

Searle, JR (1963). Speech Acts: An Essay in the Philosophy of Language. . Cambridge: Cambridge University Press.

Sudarmanto. (2009). Kinerja dan Pengembangan Kompetensi SDM. Yogyakarta: Pustaka Pelajar

Sudaryanto. (1990). Revealing the Essential Functions of Language. Yogyakarta: Duta Wacana Press.

Sudaryanto. (1993). Methods and Variety of Language Analysis Techniques (Introduction to Research on Forum for Culture Linguistically). Yogyakarta: Duta Wacana University Press.

Sudaryanto. (1993). Methods and Variety of Language Analysis Techniques (Introduction to Research on Forum for Culture Linguistically). Yogyakarta: Duta Wacana University Press.

Sugiono, PD (2011). Educational Research Methods. Bandung: Alfabeta.

Sukardi. (2010). Educational Evaluation, Principles and Operations. Jakarta: PT. Bumi Aksara.

Suryo, s. (2002). Teaching and learning process. Jakarta: Rineka Cipta. 
Suyono, D. (1990). Basics and Teaching. Malang: YES 3.

Syardiansah, et al. (2020). The Effect of Job Satisfaction and Organizational Culture on Employee Performance of the Royal Hotel in East Aceh District. Budapest International Research and Critics Institute-Journal (BIRCI-Journal). P. 849-857

Rohmadi, W. d. (2009). Pragmatic Discourse Analysis of Theory Studies. Surakarta: Yuma Pustaka.

Rusminto. (2009). Indonesian Discourse Analysis. Bandar Lampung: University of Lampung. Rustaman, 2. (2001). Asking Skills in Learning. Bandung: Depdinas.

Tarigan, HG (1987). Discourse Teaching. Bandung: Angkasa Bandung. 